\title{
Familial benign chronic pemphigus (Hailey-Hailey Disease): use of topical immunomodulators as a modern treatment option
}

\author{
GEORGI TCHERNEV ${ }^{1}$, JOSÉ CARLOS CARDOSO²
}

\begin{abstract}
Benign chronic familial pemphigus (Hailey-Hailey disease) is a rare autosomal dominant blistering skin disorder characterized by suprabasal cell separation (acantholysis) of the epidermis. The Hailey brothers first described it in 1939. Hailey-Hailey disease usually appears in the third or fourth decade, although it can occur at any age. Heat, sweating and friction often exacerbates the disease, and most patients have worse symptoms during summer. It is characterized clinically by a recurrent eruption of vesicles and bullae at the sites of friction and intertriginous areas. We report a 51-year-old male presenting with grey-brown hyperkeratosis with partial papillomatosis and lichenification in the axillary and inguinal areas and infiltrated erythematous lesions in the infraorbitary region, on the side of the face. Biopsies obtained from inguinal and axillar areas revealed parakeratotic crusts overlying an acantholytic epidermis. A biopsy from one of the lesions from the infraorbital area showed a Jessner-Kanof lymphocytic infiltration. The patient was treated with antimicrobials and four days later, topical Pimecrolimus was started, leading to an improvement of the clinical picture. The efficacy of Pimecrolimus in our case suggests that cellular immunity could play a role in the pathogenesis of Hailey-Hailey disease.

(Rev Med Chile 2010; 139: 633-637).
\end{abstract}

Key words: Acantholysis; Anti inflammatory agents, non-steroideal; Calcineurin.

\section{Pénfigo familiar crónico benigno. Informe de un caso}

El pénfigo familiar crónico benigno (enfermedad de Hailey-Hailey) es una enfermedad ampollar autosómica poco frecuente de la piel, que se caracteriza por acantolisis de la epidermis. Presentamos un hombre de 51 años que se presentó con una hiperqueratosis de color gris pardo con papilomatosis y liquenificación en las zonas axilares e inguinales y lesiones eritematosas infiltradas en la región infraorbitaria a un lado de la cara. Las biopsias que se obtuvieron de las zonas inguinales y axilares mostraron costras hiperqueratóticas sobre una epidermis acantolitica. La biopsia de las lesiones infraorbitarias mostró una infiltración linfocítica tipo Jessner-Kanof. El paciente se trató con antibióticos y cuatro días más tarde se inició pimecrolimus, mejorando el cuadro clínico.

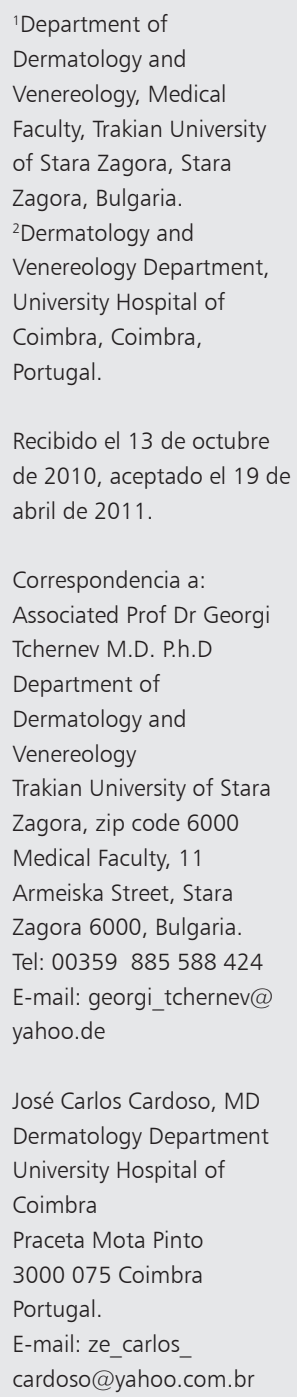


$\mathrm{B}$ enign chronic familial pemphigus (HaileyHailey disease [HHD]) is a hereditary blistering skin disease, transmitted in an autosomal dominant way with variable genetic penetrance ${ }^{1}$. It was described for the first time in 1939 by the two brothers Hugh and Howard Hailey². It is hypothesized that the main reason for the pathologic changes is an altered protein composition of desmosomes leading to acantholysis, deriving from $\mathrm{ATP}_{2} \mathrm{C}_{1}$ gene mutation localized on chromosome $3 q^{2}$. The $\mathrm{ATP}_{2} \mathrm{C}_{1}$ gene codes a $\mathrm{Ca}^{2+}$-pump that regulates the transportation of calcium from the cytosol into the Golgi apparatus ${ }^{2,3}$. In approximately $70 \%$ of the cases a positive family history may be elicited. More frequently, the disease becomes apparent during puberty, and intertriginous areas are preferentially affected, namely axillary, inguinal and neck folds. Mucous membranes are far less affected. Longitudinal white lines on the nails are frequently noticed. Bacterial and fungal super infection, maceration and frequent sweating (axillary and inguinal hyperhidrosis) are considered to be important aggravating factors ${ }^{4}$. However, some authors consider mechanical irritation to be the only provoking factor. Vesicular lesions covered by crusts, erosions and wart-like papules are other possible clinical findings. Histologically, there is acantholysis of large areas of the epidermis, giving rise to the appearance that was compared to a "dilapidated brick wall". Dyskeratosis can also be noticed ${ }^{5}$. Decomposition of the desmosome-keratin filament complex is ultrastructurally proved. Clinically, the disease has a fluctuating course, and both the activity and the affected areas may vary ${ }^{2,5}$.

\section{Case report}

A 51-year-old patient came to the clinic with skin lesions localized to the axillary and inguinal areas that were present since he was 18 years of age (figures 1-4). Topically applied therapy, including corticosteroids, antimycotics and antibiotics had been ineffective. He did not have any relatives suffering from similar lesions.

On observation, grey-brown hyperkeratosis with partial papillomatosis and lichenification were noticed in the axillary and inguinal areas (figures 1-4). Additionally, infiltrated erythematous lesions were found in the infraorbitary region, on the side of the face.
Laboratory findings: Differential blood count: neutrophils: $40.2 \%$; monocytes: $11 \%$; eosinophils: 9.8\%; triglycerides: $2.19 \mathrm{mMol} / \mathrm{L}, \mathrm{Ca}: 2.2 \mathrm{mmol} / \mathrm{L}$; blood sugar: $6.0 \mathrm{mMol} / \mathrm{L}$.

Erythrocyte sedimentation rate, hemoglobin, haematocrit, cholesterol with all subfractions, aminostransferases, GGT, electrolytes and iron were all normal. Serological test for syphilis and antistreptolysin $\mathrm{O}$ titer were negative.

Direct immunofluorescence from lesional skin and indirect immunofluorescence studies were both negative.

Histological analysis of biopsies obtained from inguinal and axillar areas revealed parakeratotic crusts overlying an acantholytic epidermis, with acantholytic cells and rare diskeratotic cells. A biopsy from one of the lesions from the infraorbital area was in keeping with Jessner-Kanof lymphocytic infiltration.

Smears for microbiologic analyses from the axillary and inguinal areas disclosed Staphylococcus aureus, E. coli and Pseudomonas aeruginosa.

\section{Treatment and outcome}

Initially, intravenous antibiotic therapy was started with flucloxacillin $2 \mathrm{~g}$ three times daily and ampicillin $1 \mathrm{~g}$ three times daily, due to the proved superinfection with Gram-positive and Gram-negative bacteria, as well as local therapy with chlorhexidin $1 \%$ aqueous solution. Four days after beginning antibiotic therapy, specific therapy with topical pimecrolimus twice a day was started, leading to a significant and fast improvement of the clinical picture.

\section{Discussion}

The differential diagnosis of familial benign chronic pemphigus includes all the most frequent skin diseases manifesting at the axillary and inguinal areas.

Pemphigus vegetans, Neumann type, is not frequently considered in the differential diagnosis. In this disease direct immunofluorescence proves deposition of $\operatorname{lgG}$ and $\mathrm{C}_{3}$-fraction of the complement, and indirect immunofluorescence shows the presence of anti-desmoglein 3 antibodies. In Hailey-Hailey disease, alterations of the humoral immunity are not found.

The clinical differentiation from inverse psoriasis is often very difficult, particularly in macerated 

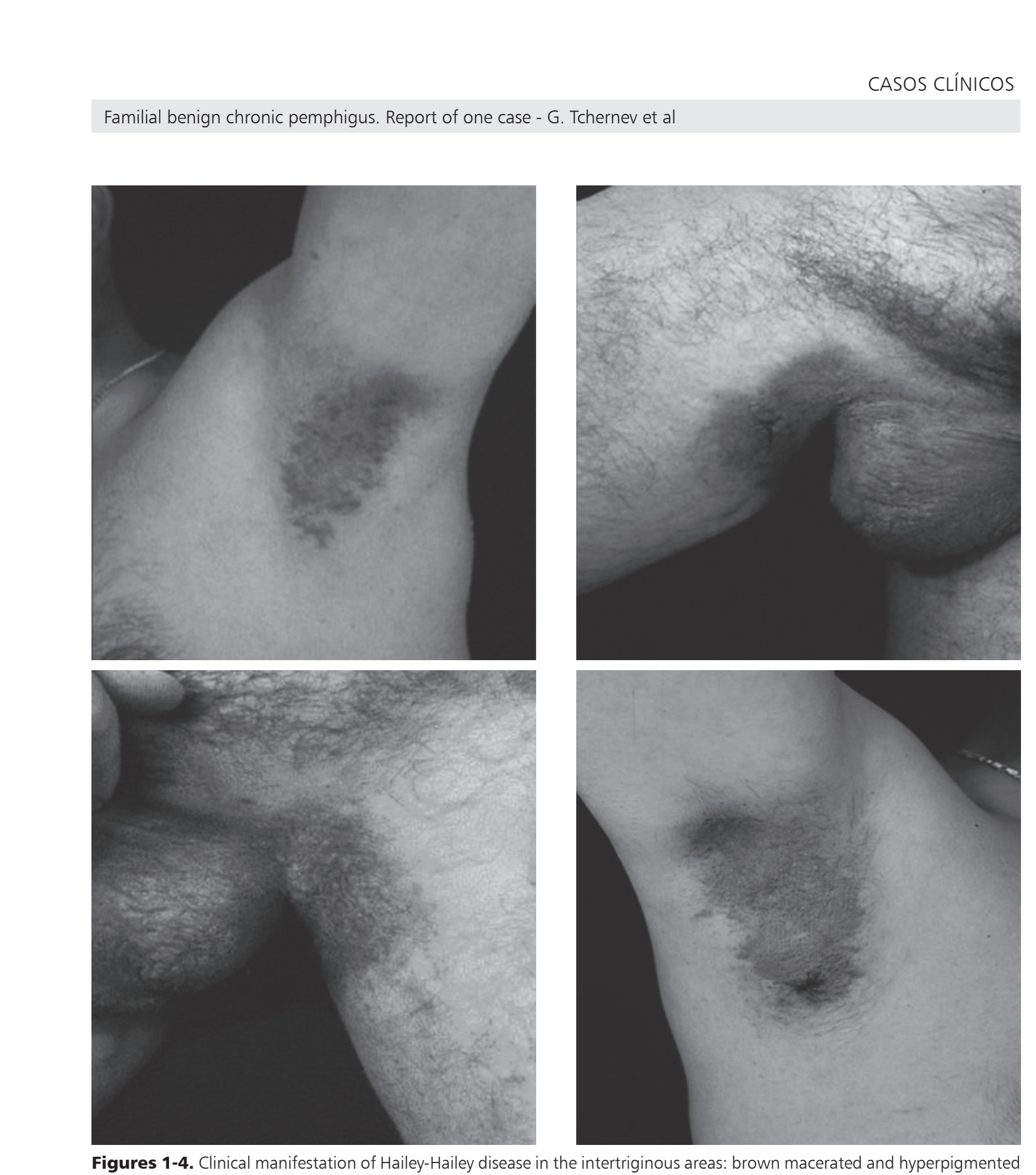

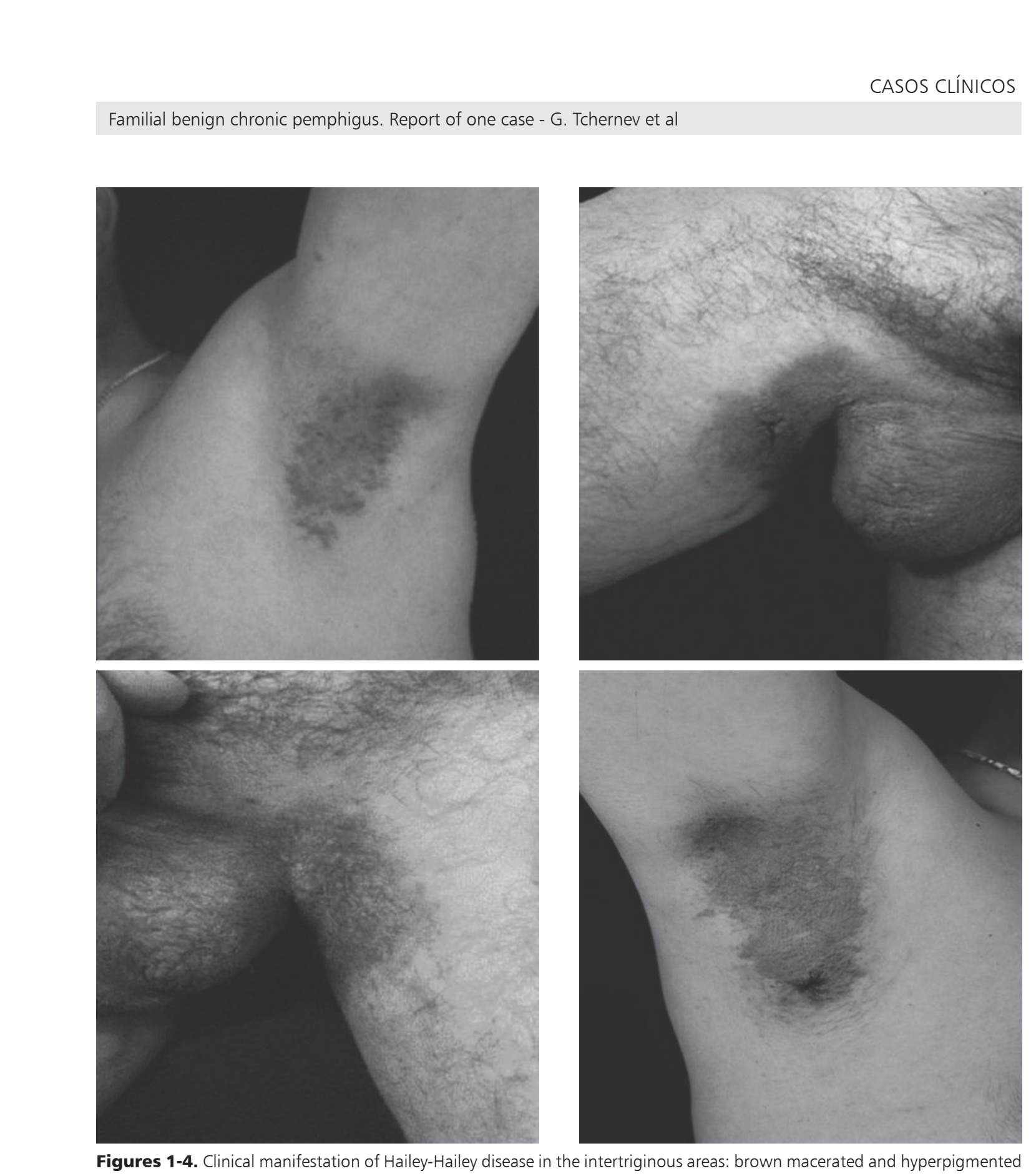
ranges at the axillary and inguinal areas.

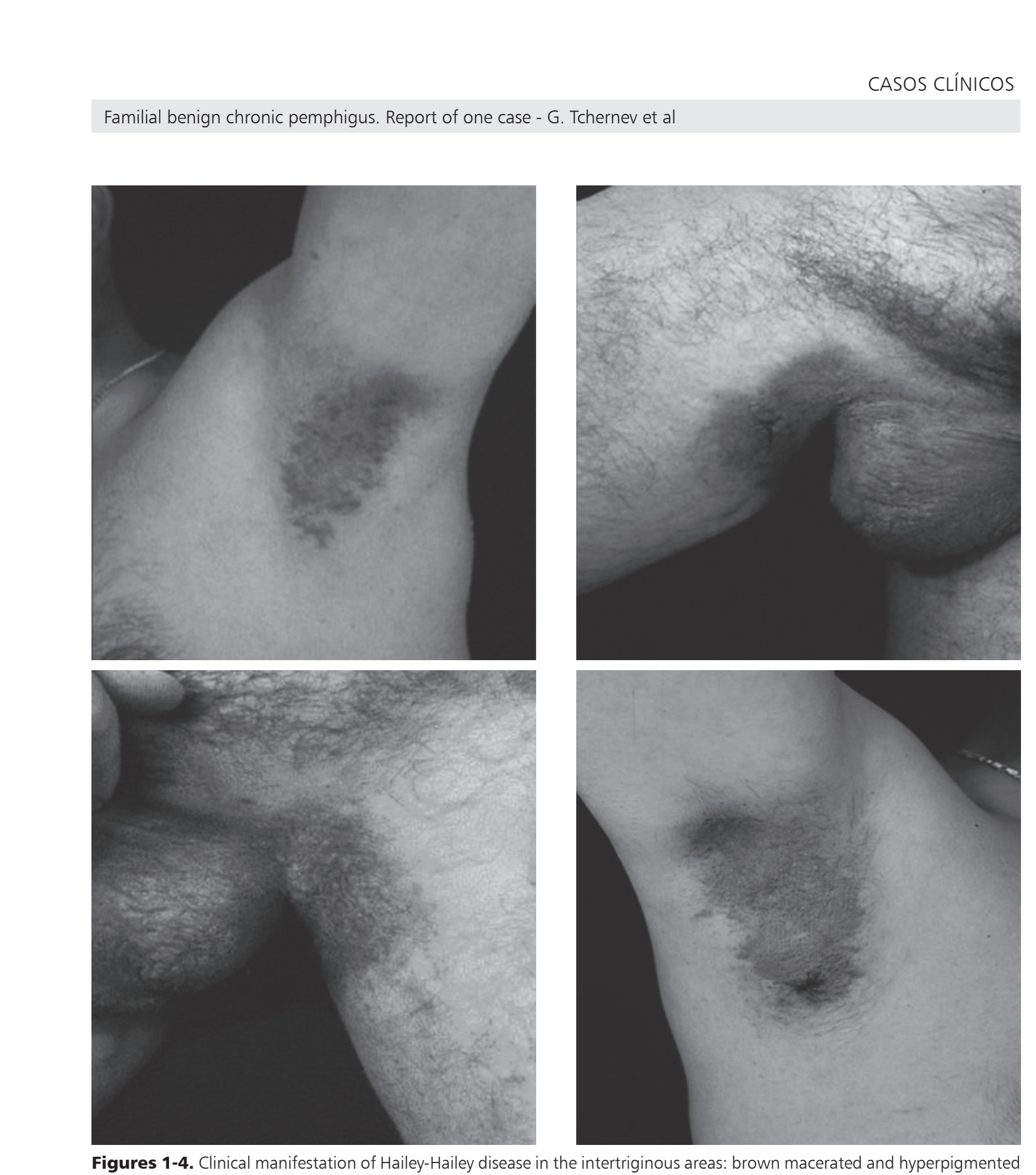
and superinfected lesions ${ }^{2,6}$. Histological features provide essential clues to the differentiation bet- ween the two diseases, as the typical acantholysis and occasional dyskeratosis found in HHD are not features of psoriatic lesions.
The diagnosis of acanthosis nigricans may also be evoked, especially in the case of hyperpig- mented lesions of HHD that may elude clinical diagnosis.

The histopathological and clinical differentiation between HHD and Darier's disease is not always easy ${ }^{2,5,7}$. In these cases the clinical picture is decisive, as is the presence of dyskeratotic cells and more focal acantholysis in Darier's disease, contrasting with the more diffuse acantholysis and less or inexistent dyskeratosis in HHD.

Candidal superinfection seems to be a frequent concomitant infection in lesions of HHD, the same 
as in inverse psoriasis and in different forms of pemphigus vegetans.

During the last years, the genetic cause and molecular pathogenesis of Hailey-Hailey disease have been elucidated. The distribution of intracellular $\mathrm{Ca}^{2+}$ plays an important role in the regulation of cell-cell interactions in the epidermis ${ }^{3}$. Damage of desmosomes gives rise to acantholysis, the characteristic finding in Hailey-Hailey disease. It is considered that the increase in cytosolic calcium, as well as its reduction in the Golgi apparatus leads to reduced glycosylation and incorrect arrangement of the intercellular adhesion molecules, i.e. of the desmosomal proteins ${ }^{2}$. The exact cause of the mutation of the $\mathrm{ATP}_{2} \mathrm{C}_{1}$ gene, which is responsible for the metabolic disorders at both cellular and sub cellular levels, remains unclear ${ }^{8,9}$.

The disclosure of the pathogenic mechanisms in Hailey-Hailey disease, as well as the creation of new medications shall probably lead to better therapeutic effect. The therapies that are usually applied, like topical corticosteroids, antibiotics, both topical and oral antimycotics, and isotretinoin are not always a successful treatment option. Chronic treatment with corticosteroids may lead to skin atrophy, telangiectasia, striae distensae and, possibly, to increased vulnerability to infections in the affected areas $^{2}$. Calcineurin inhibitors (cyclosporin $\mathrm{A}$, tacrolimus and pimecrolimus), initially introduced for post-transplant immunosupression, proved also useful for some inflammatory skin diseases, namely atopic eczema ${ }^{2}$.

During last years, tacrolimus and pimecrolimus were studied and showed a very favorable clinical effect both in short and long duration treatments in patients with atopic dermatitis and, consequently, these molecules gained recognition as good topical immunomodulators ${ }^{2,11}$. The topical application of both preparations is not associated with any of the undesirable side effects arising after oral treatment with cyclosporin A. Pimecrolimus penetrates less through the skin and this leads, at least theoretically, to less risk of systemic effects compared to tacrolimus ${ }^{2}$. Pimecrolimus shows a higher affinity to epithelial structures, but its affinity to lymphoid structures is lower compared to tacrolimus ${ }^{2}$.

Tacrolimus, pimecrolimus and cyclosporin A block calcineurin in the cytoplasm and lead to suppression of T-cell function. Tacrolimus and pimecrolimus achieve these effects through the initial linkage to the cytosolic receptor FKBP-12, designated also as macrophillin-12 $2^{2,10}$. In contrast to them, cyclosporin A binds to another cytosolic receptor from the macrophillin group, the cyclophillin ${ }^{2}$. The macrophillin- $12-\mathrm{Cl}$ complex blocks the calcineurin phosphatase and this leads to activation (through dephosphorylation) of NFAT (nuclear factor of activated T-cells). This blocks the transportation of NFAT to the nucleus, inhibiting the synthesis of immunomodulatory cytokines: IL-2, IL-4, IL- 8 , TNF- $\alpha$ and $\gamma$-interferon. Consequently, there is impairment in the proliferation of T-cells that participate and maintain the inflammatory process. Pimecrolimus also blocks the expression of the receptors that take part in the processes of differentiation of the T-cell population ${ }^{2,12}$.

An important advantage of both medications is that they do not block the synthesis of collagen in skin fibroblasts and do not lead to atrophy, in contrast to topical corticosteroids. The immunosuppressive effect of pimecrolimus is weaker than that of tacrolimus ${ }^{2}$.

This allowed also the application of a modern pathogenic approach leading to a quick control of clinical skin abnormalitie without inducing the side effects usually associated with corticosteroids ${ }^{11,12}$. A successful treatment of patients suffering from Hailey-Hailey disease applying tacrolimus has been described in the literature ${ }^{12}$, and this makes us provide this information about the favorable local treatment held with pimecrolimus.

In untreated skin lesions of Hailey-Hailey disease, a significant infiltration with T-lymphocytes has been demonstrated in previous works, considerably decreasing after the therapy not only with tacrolimus and pimecrolimus, but also with cyclosporin- $\mathrm{A}^{2}$.

The cause of T-cell infiltration in Hailey-Hailey disease is not clear yet. The fast beneficial impact of immune regulators on skin symptoms suggests, however, that T-lymphocytes play some role in the pathogenesis of the disease.

The specific effect of tacrolimus and pimecrolimus, blocking the pathologic T-cellular response shows that in the pathogenesis of Hailey-Hailey disease, additionally to the genetic defect, a dysregulation of the cellular immune response is also present. Suppression of the proliferation of T-cells by pimecrolimus quickly controls the acantholysis in this disease ${ }^{2}$. 
Topical pimecrolimus treatment applied in the form of cream twice a day led, in the present case, to a quick response of skin lesions. During the therapy no side effects were noticed, neither local, such as itching or burning sensations, nor any systemic complaints.

\section{References}

1. Ding YG, Fang H, Lao LM, Jiang XJ, Chen HC. Genetic diagnosis of Hailey-Hailey disease in two Chinese families: novel mutations in the ATP2C1 gene. Clin Exp Dermatol 2009; 34: e968-71.

2. Tchernev G, Zouboulis CC, Orfanos C. Treatment of Morbus Hailey-Hailey with pimecrolimus. Bulgarian J Dermatol Venereol 2004; 153: 37-40.

3. Leinonen PT, Hägg PM, Peltonen S, Jouhilahti EM, Melkko J, Korkiamäki T, et al. Reevaluation of the normal epidermal calcium gradient, and analysis of calcium levels and ATP receptors in Hailey-Hailey and Darier epidermis. J Invest Dermatol 2009; 129: 1379-87. Epub 2008 Dec 4.

4. Hamada T, Fukuda S, Sakaguchi S, Yasumoto S, Kim SC, Hashimoto T. Molecular and clinical characterization in Japanese and Korean patients with Hailey-Hailey disease: six new mutations in the ATP2C1 gene. J Dermatol Sci 2008; 51: 31-6.

5. Wilgram GF, Caufield JB, Lever WF. Electron microscopic studies in skin diseases with acantholysis (pemphi- gus vulgaris, pemphigus familiaris benignus chronicus, Darier's disease). Dermatol Wochenschr 1964; 147: 281-92.

6. Stoianov S, Ivanov I. [Case of Hailey-Hailey disease (pemphigus chronicus benignus familiaris).] Izv Meditsinskite Inst Bulg Akad Naukite Sofia Otd Biol Meditsinski Nauki 1955; 11-12: 565-74.

7. Kovaks Z. [On the relationship between bullous form of Darier's disease (dyskeratosis follicularis typ bullosus) and Hailey-Hailey disease (pemphigus benignus chronicus familiaris)]. Borgyogy Venerol Sz 1960; 36: 7-13.

8. Cheng TS, Ho KM, Lam CW. Heterogeneous mutations of the ATP2C1 gene causing Hailey-Hailey disease in Hong Kong Chinese. J Eur Acad Dermatol Venereol. 2010 Mar 4. [Epub ahead of print].

9. Ma YM, Zhang XJ, Liang YH, Ma L, Sun LD, Zhou FS, et al. Genetic diagnosis in a Chinese Hailey-Hailey disease pedigree with novel ATP2C1 gene mutation. Arch Dermatol Res 2008; 300: 203-7. Epub 2008 Feb 8.

10. Persić-Vojinović S, Milavec-Puretić V, Dobri I, Rados J, Spoljar S. Disseminated Hailey-Hailey disease treated with topical tacrolimus and oral erythromycin: Case report and review of the literature. Acta Dermatovenerol Croat 2006; 14: 253-7.

11. Ferraro V, Adamski H, Le Gall F, Chevrant-Breton J. [Efficacy of topical tacrolimus in Hailey-Hailey disease]. Ann Dermatol Venereol 2006; 133 (5 Pt 1): 475-6.

12. Rocha Paris F, Fidalgo A, Baptista J, Caldas LL, Ferreira A. Topical tacrolimus in Hailey-Hailey disease. Int J Tissue React 2005; 27: 151-4. 